\title{
A Multi-Hazard Historical Catalogue for the City- Island-State of Malta (Central Mediterranean)
}

\author{
Ritienne Gauci \\ University of Malta \\ John Schembri \\ University of Malta \\ David Chester \\ University of Liverpool
}

Geoff Main ( $\square$ g.main@exeter.ac.uk)

University of Exeter Cornwall Campus https://orcid.org/0000-0001-8453-1527

\section{Research Article}

Keywords: Malta, environmental hazards, historical catalogue, disaster risk reduction.

Posted Date: October 25th, 2021

DOI: https://doi.org/10.21203/rs.3.rs-1000028/v1

License: (9) This work is licensed under a Creative Commons Attribution 4.0 International License.

Read Full License

Version of Record: A version of this preprint was published at Natural Hazards on June 16th, 2022. See the published version at https://doi.org/10.1007/s11069-022-05403-x. 
1 A multi-hazard historical catalogue for the city-island-state of Malta (Central

2 Mediterranean)

3 Authors

4 Geoff Main, Centre for Geography and Environmental Science, University of Exeter, Penryn,

5 UK; g.main@exeter.ac.uk; ORCID: 0000-0001-8453-1527

6 Ritienne Gauci, Department of Geography, University of Malta, Malta;

7 ritienne.gauci@um.edu.mt; ORCID: 0000-0002-4496-3138

8 John A. Schembri, Department of Geography, University of Malta, Malta;

9 john.a.schembri@um.edu.mt

10 David K. Chester, Department of Geography and Planning, University of Liverpool, UK; jg54@liverpool.ac.uk; ORCID: 0000-0001-8722-360X

\section{Abstract}

The city-island-state of Malta is traditionally viewed as a low-hazard country with the lack of a long historical catalogue of extreme events and their impacts acting as an obstacle to formulating evidence-based policies of disaster risk reduction. In this paper, we present the first multi-hazard historical catalogue for Malta which extends from the Miocene to 2019 CE. Drawing on over 3,500 documents and points of reference, including historical documentary data, official records and social media posts, we identify at least 1,526 hazard events which collectively have caused the loss of at least 661 lives. Recognising that historical materials relating to Malta are complicated by the presence of a strong temporal bias, we establish a fourpoint reliability indicator and apply this to each of the 1,062 recordings, with the result that some $78 \%$ show a high degree of reliability. For an island state where there are significant gaps in the knowledge and understanding of the environmental extremes and their impacts over time, this paper addresses and fills these gaps in order to inform the development of publicfacing and evidence-based policies of disaster risk reduction in Malta.

\section{Keywords}

Malta; environmental hazards; historical catalogue; disaster risk reduction.

\section{Statements and Declarations}

Conflict of interest: The authors have no competing interests to declare that are relevant to the content of this article.

Funding: This research and manuscript was funded by a Liverpool Hope University Vice Chancellor's Scholarship and a University of Malta Research Seed Fund 2021.

\section{Acknowledgements}

The authors wish to acknowledge the support and encouragement of Kevin Crawford, Janet Speake, Victoria Kennedy, Angus Duncan, Chris Kilburn, Pauline Galea, Sandra Mather, Mary Rice and staff at the Times of Malta, National Library Valletta, the University of Malta Library and Archives, the National Archives Rabat and the Cathedral and Order of Malta Archives. We are also grateful to Anthony Hepworth for permission to use his photograph presented in Fig. 4c. Ethical approval for this research was granted by Liverpool Hope University in December 2016. 


\section{Introduction}

Islands have been long-represented as having high levels of exposure to environmental extremes owing to the complex interplay of a variety of factors (Pelling and Uitto 2001; Méheux et al. 2007; Wisner and Gaillard 2009). Recent research has found that this is particularly apparent for advanced, independent and heavily urbanised island states, such as the city-island-state of Malta (Main et al. 2021). There is some research which has considered the hazardous history of economically more advanced islands and archipelagos where hazards occur frequently and/or where there are frequent reminders of the hazardousness of the place. Examples include work in: Iceland, Sicily and the Canarian and Azorean archipelagos (e.g. Barbano and Rigano 2001; Gaspar et al. 2015; Galindo et al. 2020). It is only relatively recently that the complex exposure and hazard history of city-island-states has, however, been considered. Here extreme natural events may be relatively infrequent, but the impacts are highly significant given the state's level of economic and physical development with even modest events having severe financial consequences as a measured proportion of GDP (e.g. Main et al. 2018; Agius et al. 2020).

\subsection{Malta}

The city-island-state of Malta, also known as the Maltese Islands, is a small, European Union (EU), archipelagic island state comprising three principal islands: Malta $\left(246 \mathrm{~km}^{2}\right)$; Gozo $\left(67 \mathrm{~km}^{2}\right.$ ) and Comino (2.7 km²) (Schembri 2019; Main et al. 2021). Located in the central Mediterranean (Fig. 1) some $90 \mathrm{~km}$ south of Sicily, Malta is one of the most densely populated countries in the world with a resident population of over 0.5 million people and total density of 1,628 persons per $\mathrm{km}^{2}$ (National Statistics Office 2020).

Lying in a northwest-southeast direction in the Sicily Channel, Malta is surrounded by subduction structures and smaller, though no less active, major faults including the HybleanMalta Escarpment, together with those comprising the Sicily Channel Rift Zone and the Pantelleria Rift (Fig. 1; Baldassini and Di Stefano 2016; Galea 2019). The city-island-state is dissected by two systems of faults: predominantly northeast-southwest trending faults, such as the inactive Great Fault; and those trending northwest-southeast that include the Maghlaq Fault off Malta's south-west littoral (Villani et al. 2018; Gauci and Scerri 2019). The stratigraphy of Malta comprises a five-layered sequence of sub-horizontal Oligocene-Miocene carbonate sediments and clays (Pedley et al. 2002; Scerri 2019; Chatzimpaloglou et al. 2020). These are, from youngest to oldest: Upper Coralline Limestone; Greensand; Blue Clay; Globigerina Limestone and Lower Coralline Limestone. As a result of this tectonic and geological setting, 
the archipelago is home to a varied suite of landforms that include: limestone plateaux; high cliffs; drowned coastlines (rias); drowned and erosional shorelines; highly incised former river valleys (widien), up to several kilometres long and tens of metres deep, and a $14 \mathrm{~km}$ long horstand-graben sequence extending north-north-west from the Great Fault (Alexander 1988; Furlani et al. 2017; Gauci and Scerri 2019; Furlani et al. 2021). Malta's climate is typical of the semi-arid Mediterranean, with hot dry summers and warm wet winters. Some $85 \%$ of annual rainfall (c. $530 \mathrm{~mm}$ ) falls between October-March and mean monthly temperatures range from $12{ }^{\circ} \mathrm{C}$ in January to $26^{\circ} \mathrm{C}$ in July (Galdies 2011; Schembri 2019).

In spite of this complex setting and physical geography, Malta has been traditionally viewed as a low-hazard country, not considered disaster prone and sometimes styled as the "safest place on Earth" (Camilleri 2011; Appleby-Arnold et al. 2018). Originating from an international disaster risk index, the World Risk Index, it has been argued that such viewpoints may potentially engender a false sense of security amongst the population (Main et al. 2018). Among critiques of indices such as these, it has been pointed out that such assessments are based on inadequately researched and incomplete historical catalogues of damaging events (Main et al. 2018). The Sendai Framework for Disaster Risk Reduction 2015-2030 identifies, not only the importance of an integrated multi-hazard approach to disaster risk reduction (DRR), but also the requirement for knowledge, and the sharing of knowledge, on extreme events that have impacted a location throughout its history to better identify disaster risk and inform and shape policies of sustainable development within the context of DRR (United Nations 2015). In their work reviewing the international rankings of Malta in terms of hazard exposure, Main et al. (2018) identify a lack of long historical records of extreme events and their impacts, which is currently acting as one of the principal obstacles to the formulation of detailed hazard assessments and evidence-based policies of DRR in this densely populated nation. Existing policies are limited, with their principal focus being on hazards associated with pluvial storm flooding.

In Malta the literature on hazards is dominated, either by the reporting and cataloguing of discrete events such as earthquakes (e.g. Abela 1969; Galea 2007; Agius et al. 2020), dolines (e.g. Calleja 2010) or pluvial storm flooding (Malta Resources Authority 2013) or is focused on the evidence for extreme events in the past: their causes; processes of initiation and their impacts. This has included work on past tsunamis (Biolchi et al. 2016; Causon Deguara and Gauci 2017; Mottershead et al. 2018) and geomorphological phenomena including landslides, rock fall, sea-arch collapses and dolines (Mantovani et al. 2013; Prampolini et al. 2018; 
Satariano and Gauci 2019; Devoto et al. 2021). Recent research has not only criticised the catalogue of, and policies associated with, pluvial storm flooding, but has also highlighted that Malta is exposed to a much wider range of environmental extremes than has been commonly supposed (Jones 2018; Main et al. 2018; Main 2019). Following major events, such as severe storms (e.g. 28 February 2019), significant coastal erosion (e.g. 8 March 2017) and local or regional earthquakes (e.g. 7 July 2003), attention to Malta's hazardous history is renewed, but this soon fades from public consciousness. The need for knowledge, awareness and research into the hazards, threats and risks facing Malta is both recognised and, indeed, is called for within Malta's first National Risk Assessment (NRA) compiled in 2015 and which forms a principal objective of the competent authorities' risk reduction and management strategy (European Commission 2016, p. 43).

In this paper and accompanying supplementary material (Table S1) we publish Malta's first multi-hazard historical catalogue in which geophysical, geomorphological and meteorological extremes are recorded, identified and in some cases inferred, from the Miocene epoch (c. 23-c. $25 \mathrm{Ma}$ ) to 2019 CE. In so doing we aim to address significant gaps in knowledge and understanding on environmental extremes and their impacts on Malta from geological times until the present day.

\section{Methodology}

Works exploring the hazardous history of diverse places have drawn upon a range of historical data which have included: maps; pictorial sources; government and nongovernmental archives; newspapers of record; diaries; correspondence; parish records; oral histories; military archives and early scientific publications and communications (e.g. Branca and Del Carlo 2004; Macdonald et al. 2010; Riede 2014). In the case of Malta, however, the availability of historical data is complicated by strong temporal bias.

Documents relating to the history of Malta date mainly from after the time of the arrival of the Order of St. John of Jerusalem (Knights of St. John) in 1530 and there is a marked absence of documents from the time of Islamic occupation (870-1090 CE). Texts relating to the early years of the British occupation were destroyed in the 1870s whilst a large quantity of pre-1500 texts were either destroyed or removed from Gozo by the invading Turks in 1551 (Galea 2007; Main 2019). With the exception of early texts which provide some rudimentary data on natural phenomena, newspapers from the second half of the nineteenth century provide what is considered the best source of information regarding past environmental extremes. For 
the texts that have survived from the period of the Knights of St. John and later, there is a predominance of pre-1846 materials in the collections of contemporary literate individuals within the archives of the: Cathedral and Inquisition; Order of Malta; Religious Orders and University of Malta. Some of the texts which survived the destruction of the 1870s are housed in the National Archives at Rabat (Malta).

In spite of such unavoidable limitations, in constructing the first multi-hazard historical catalogue a range of historical documentary data, official records and social media posts have been examined covering over 3,500 documents and media (Main 2019, p. 68-74). These include: contemporary newspapers of record, including the Times of Malta and its sister paper the Sunday Times of Malta, alongside the Malta Herald, Malta Today, Malta Independent, Daily Malta Chronicle and international newspapers of record such as The Times of London; texts of learned and literate individuals comprising diaries, letters and personal correspondence; previous scholarly and official reports and listings, including major works by Abela (1969), Galea (2007), Calleja (2010), the Malta Resources Authority (2013) and Agius et al. (2020) and photographs and maps archived by the University of Malta, National Library and National Archives. Digitised versions on various web-based platforms have also been consulted.

While the use of these data has proved fruitful in constructing this multi-hazard historical catalogue, there are some limitations. First, there is a low sensitivity to small-scale events both within the contemporary newspapers of record, with their focus skewed on 'news of the day' and in 'event-oriented' stories, and records left by individuals (Raška et al. 2014). This is particularly apparent in accounts of earthquakes in the pre-1995 period before the first instrumental seismometer was installed (Galea 2007; Agius et al. 2020). In exploring media archives, several search terms were used to identify historic hazardous events. These included: storm, quake, tremor, earth-movement, shake, flood, gale, land-slide, rock-fall, temperature and snow. Terms such as rain, precipitation and wind were discounted because they produced records of forecasts or overall observations, not known and recorded events. Finally, media reports often present a spatio-temporally scattered account of past events, a limitation particularly notable for geomorphological extreme events. For example, it is commonplace for events to be recorded within historical texts if and when they were of such significance that they caused threats to human life, property and/or infrastructure. It is because of factors such as these that we recognise that some gaps remain in our catalogue. 


\subsection{Reliability Indicator}

In assembling and presenting our multi-hazard catalogue a four-point reliability scale (Table 1) has been used, which is adapted from Maramai et al. (2014). In the case of this catalogue, this is particularly important because firm supporting data for events may not exist and/or some elements (e.g. date, magnitude, locations affected) may remain either unknown or questionable. As this is the first catalogue of its type for Malta, all events that have been identified within the records are included, but the reliability indicator has been added to demonstrate the dependability of each recording. Of the 1,062 recordings $51 \%(n=544)$ have a reliability of 3, followed by $27 \%(n=290)$ of $4,20 \%(n=217)$ of 2 and $1 \%(n=11)$ of 1 . This shows that overall reliability of the catalogue is strong, with the majority of entries being definite or confirmed. Within the catalogue, it is important to distinguish between a record and $a(n)$ event(s): a record represents the original data source (e.g. a newspaper article, diary extract, photograph or video), whilst an event is what is being described within the record. There is clearly, therefore, the possibility that more than one environmental extreme may be described within a recording and these have thus been counted separately within the catalogue.

\section{The Catalogue}

Drawing upon the range of data discussed above, we have compiled the first multihazard historical catalogue for Malta describing events which range in occurrence from the Miocene to 28 February 2019 (Table S1). In total, 1,526 individual events have been identified which have caused at least 661 human fatalities. This represents a significant advance in understanding and demonstrates that, in contrast to the opinion that Malta is a low-hazard country, there is not one district in the city-island-state that has not been exposed to at least one of the environmental extreme events that are identified in Table 2.

Although the total counts may seem small, four factors need to be emphasised. First, it is "only because of the probabilistic nature of extreme events impacting vulnerable people that [the island state] has not been more severely affected in recent years" (Main et al. 2018, p. 131). Secondly, rapid and ongoing expansion of the urban footprint, including significant coastal development with over $35 \%$ of Malta's littoral classified as urban in 2017 (up from 5 $\%$ in 1990), is making areas and their increasing population more exposed and vulnerable than they were in the past (Schembri 2003; Vella et al. 2005; Ciarlò 2017; Main et al. 2021). Thirdly, it is highly probable given the nature of the evidence discussed in Sect. 2 and below that other events may still remain unrecorded. Finally, the total count recorded is the minimum number of hazardous events that can be identified. For example, the record of the 1657-March 1658 
earthquakes merely identifies: "a series of earthquakes". Recognising that "a series" constitutes more than 1 event, this and similar events have been totalled at 2 in this catalogue. Before demonstrating the variety of environmental extremes and their impacts over time (Sect. 3.1), we first discuss our findings in relation to the reliability indicator and the available evidence, identify spatial patterns and triggering processes and finally outline the possible cascading effects which may be brought about by climate change.

The overall reliability within our multi-hazard historical catalogue is strong with the majority of records having a reliability of 3 or 4 (Sect. 2.1). Within this four key findings may be identified: (1) over $60 \%$ of meteorological extremes have a reliability of 4 , compared with, respectively, $10 \%$ and $50 \%$ for geophysical and geomorphological; (2) the majority of geophysical extremes have a reliability of $3(64 \%)$, followed by 2 (24\%); (3) the records relating to geomorphological extremes show a greater spread of reliability and (4), over $90 \%$ of records with a ranking of 1 represent geophysical extremes of which earthquakes and tsunamis are dominant. These findings are the result of the temporal bias within, and nature of, the records used to compile the catalogue. This is most clearly seen in the context of tsunamis for which records of impact on the island state are complex. In the case of tsunamis dating from geological times, debate over their generation, origin of erosional features and deposits found along low-lying coasts has been intense (Carroll et al. 2012; Causon Deguara and Gauci 2017; Tappin 2018; Fig. 2a, b). In contrast, where written records, models and maps exist, it is possible to make inferences about the ways in which historic tsunamis impacted the archipelago. Combining these data with existing Mediterranean tsunami catalogues (e.g. Tinti et al. 2004; Maramai et al. 2014), it has been possible to infer that tsunamis in c. 8,000 years BP, 21 July 365 CE, 4 February 1169 and 20 February 1743, impacted the coastline of the archipelago (Pareschi et al. 2006; Pararas-Carayannis 2011; Biolchi et al. 2016; Mottershead et al. 2018; Main 2019). Conversely, the use of historical texts in relation to meteorological and geomorphological phenomena must be treated with caution as they often lack a temporal framework required for event identification and inclusion within the catalogue. An example of this is information within the first literary text written in the Maltese language, Il-Kantilena (Fig. 2c) by Pietru Caxaro sometime pre-1485, yet not recorded until December 1533-May 1563. The poem is widely considered to refer to the collapse of a homeowner's property by ground subsidence due to the unstable geological foundations (Gauci and Schembri 2019), but its attribution and true meaning may be debated (Main 2019, p. 74). In marked contrast, events with a high reliability and that occurred post-1850, and more notably after 2000 , are ones in 
which there are multiple records in newspapers, and/or other printed sources and on social media (Fig. 2d; Alexander 2014; Main 2019).

Examining the catalogue enables identification of the spatial patterns and triggering processes of environmental extremes which have impacted the archipelago. This is most clearly seen in the context of geomorphological events which are triggered by local in-situ geological and tectonic forces. For example, forms of mass movement (e.g. rock-fall, lateral spreads, block-slides) are common along extensive areas of the north Malta and east Gozo coasts and are directly associated with the geological setting, generally, and the northeast-southwest trending faults more particularly (e.g. Fig. 3; Devoto et al. 2012; Prampolini et al. 2018; Soldati et al. 2019; Devoto et al. 2021). Although there are instances of rock-falls and landslips inland within our catalogue, these are largely the consequence of erosion and collapse of fissures within the Globigerina Limestone formation and historic bastion defences with some successful mitigation measures being installed to protect heavily visited historic sites such as Mdina (Bonnici et al. 2008; Gigli et al. 2012). Similarly, ground collapse is largely associated with such in-situ processes with Calleja and others identifying the importance of bedrock geology and faulting (Pedley 1974; Calleja 2010; Soldati et al. 2013). Across these geomorphic hazards, the Blue Clay lithology is a key factor owing to its relative 'plasticity' (Mantovani et al. 2013). As Malta witnesses the ongoing and rapid expansion of the urban footprint on to areas associated with this lithology, coupled with other anthropogenic land-use changes, it is possible that the occurrence of such extremes may accelerate and begin to impact previously uninhabited areas (e.g. Gutiérrez et al. 2014).

By contrast, the geophysical and meteorological extremes recorded within this catalogue, triggered by ex-situ regional tectonic and atmospheric processes, are more challenging to identify in terms of their spatial patterns. Some spatial patterns may, however, be identified. First, by nature of the archipelago's geography extreme wave events and seiches are more likely to have an impact along the low-lying northern and eastern coasts and bays of the archipelago with significant threats to land use and critical infrastructure (Main 2019, p. 109-122; Mueller et al. 2020). As such areas continue to become commodified and increasingly more urban, the risk from future events increases in significance. This is particularly apparent during the summer months owing to the influx of vulnerable tourists, with 1.7 million people visiting between April-September 2019, and research finding not much interaction and collaboration between policy-level stakeholders considering DRR in Malta's tourism industry (Morrison 2013; Main 2019; Kennedy et al. 2020; Malta Tourism Authority 2020). The 
competent authorities concerned with DRR in Malta have installed a series of enhanced sealevel gauge infrastructure around parts of this coastline with the aim of providing an early warning to the authorities and local communities (Gauci 2021). The threat posed by flooding meanwhile is largely concentrated in low-lying areas and is associated with widien (Sect. 1.1; Malta Resources Authority 2013; Main et al. 2018, p. 845). As development has continued to encroach across these areas since 1964 (i.e. following independence from British rule) it has been suggested that Malta experiences "flooding by design" (Schembri 2010). Since the time of the Knights of St. John and recognising the physical, economic and environmental threat posed by flooding, several legislative mitigation measures have been established. Recently these include the $€ 52$ million National Flood Relief Project that adopted a multi-catchment approach across five flood-prone areas with extensive hard infrastructure benefitting c. 4,500 properties (AIG Malta 2017; Main 2019, p. 208-211).

Finally, climate change is a serious global concern with the Sixth Assessment Report of the Intergovernmental Panel on Climate Change (IPCC 2021) identifying the Mediterranean region as an area that by mid-century will see an increase in drought, aridity, temperature extremes, increase in extreme weather events and rises in mean and extreme sea levels. Many of the environmental extremes identified within our catalogue may be linked to the cascading effects of climate change. For example increasing incidences of extreme weather with possible resultant increases in, for example, flooding and coastal erosion particularly in areas where Blue Clay crops out at sea level (Ciarlò 2017). Climate change is expected to have significant impacts across Malta including: flooding of coastal areas due to sea-level rise and increasing storminess; drought stress on agriculture and water supplies and extreme weather events with impacts on coasts, structures, infrastructure, crops and subsequently human health (Ciarlò 2017). In the case of the latter, Attard (2015) has found significant impacts are likely on the transport network, critical port and other structures along the coast, all of which contribute significantly to the national economy and play an important role in future island development. Moreover, the predicted $0.34-0.63 \mathrm{~m}$ rise in local sea-level by 2100 (IPCC/NASA 2021), together with increases in episodes of extreme weather, pose a serious threat to the coastal populations.

\subsection{Selected Event Descriptions}

23 September 1551 (or 1555/1556)

Occurring on 23 September in either 1551, 1555 or 1556 (sources differ but many believe that it occurred during 1555 or 1556 during the tenure of Grand Master Fra' Claude de 
la Sengle), the Grand Harbour was hit by an EF-3 (McDonald 2002) tornadic waterspout with winds gusting 218-233 $\mathrm{km} \mathrm{h}^{-1}$. The tornado began its life as a waterspout in the Harbour before moving inland causing extensive damage to settlements believed to include Isla, Birgu and the Forts of St. Elmo and St. Michael, the foundation stone of Valletta not being laid until 1566. In addition to the damage to settlements, four galleys of the Knights of St. John were destroyed. At least 600 people were killed and it is not known how many were Maltese, Knights, or how many may have recovered from their injuries (Anon 2017a).

\section{January 1693}

The earthquake of 11 January 1693 was arguably one of the largest catastrophes in Malta's hazardous history. With an epicentre in Sicily, a magnitude of 7.4 and recorded EMS98 intensities in Malta of VII-VIII, the earthquake caused widespread damage across the island state with reports focused on the impact felt in the major settlements of the period, notably: Valletta, Birgu, Bormla, Isla, Mdina and Victoria (Abela 1969; Galea 2007; Main et al. 2018). The earthquake triggered rock falls in some hillside and cliff areas, notably on Gozo, with an intensity $\mathrm{V}$ tsunami recorded along the low-lying coasts and in the fishing village of Xlendi (Camilleri 2006; Biolchi et al. 2016).

Following the earthquake, a special commission instituted by the Knights of St. John carried out a detailed study of the impacts from the earthquake and found that within the capital, Valletta, "there was not one house that did not need some repair", with some having to be demolished (Galea, 2007 p. 732). Damage was particularly apparent to ecclesiastical infrastructure and around one-third of the houses across Malta were raised to the ground as people fled their homes and slept outside, in shelters, underground or on board ships (Shower 1693; Main et al. 2018). Some contemporary reports suggest that the earthquake was correlated with an eruption of Mount Etna (Sicily) during which "the whole Top of the Mountain appeared all in Flames" (Shower 1693, p. 14). These reports are not, however, supported by historical catalogues and records of Etnean eruptions during this period (Branca and Del Carlo 2004; Branca et al. 2015).

\section{3-23 October 1951}

Events in October 1951 included a record-breaking monthly rainfall of $584.32 \mathrm{~mm}$, with 1951 remaining the wettest year on record. A waterspout c. 8 miles off the Grand Harbour was the first sign of instability on 3 October, followed by the first pluvial storm on 4 October that left almost every house along Valley Road in Msida ankle-knee (0.6-0.9 m) deep in water, 
two people died and extensive damage was caused to fields, crops and transport infrastructure. It would later take almost 24 hours to pump water out of homes with many fields remaining underwater throughout October. Overnight on 14-15 October, the storms returned causing extensive damage across the islands with houses flooded and others collapsing due to the wind and rain. Some people had narrow escapes from injury and death when farm buildings collapsed in Gozo.

Further storms on 17 October left three people dead and eight injured, c. 120 buildings collapsed or were badly damaged, with some homes in Birkirkara and Msida standing in $1.2 \mathrm{~m}$ of water. Upon seeing the waters rising, many residents in Msida self-evacuated to homes of friends or neighbours higher up the valley. Two days later, basements and cellars were flooded, with hailstones - some reported with a diameter of $40 \mathrm{~mm}$ - adding to building damage; ship schedules providing much needed food and public water supplies were also impacted. The final storms on 22-23 October flooded houses in Msida and Marsa with over $1.2 \mathrm{~m}$ of water with some buildings collapsing in Valletta and Birkirkara.

\section{September 1980}

In the mid-afternoon of 5 September, Golden Bay, a popular sandy beach resort on the northwest coast of Malta, was crowded with hundreds of bathers. At around 14:45 LT $(G M T+1)$, the lowermost section of the northern side of the Ghajn Tuffieha headland broke off in a large rock fall into the Bay. Contemporary reports recorded the occurrence of an earthquake during the event, but it is uncertain whether this was the cause, whether the rock-fall was merely a response to geomorphological processes or whether seismic activity acted as a triggering or enhancing mechanism. Only three people were injured when rocks fell 80-100 m from their paddleboat and the most serious injuries were a punctured lung, broken bones and superficial head injuries.

Despite feelings of fear and alarm, reports of panic may be considered journalistic licence given the accepted definition of the latter within hazard studies (der Heide 2004, p. 342). Although many people were frightened and alarmed, with many rushing inland fearing a large wave, they still acted rationally and quickly in rescuing the injured and searching for any other injured victims (Anon 1980). In 2015, one of the officials who witnessed this event recalled in the Times of Malta: "When I saw the cliff coming down, we got on a speedboat and shot off. Boulders tumbled down on to each other, spewing rocks across the bay. I thought I'd be looking for bodies. It was a miracle that nobody got killed. It was unbelievable. The 
paddleboat [on which three people were injured] looked like it had been bombarded" (Carabott 2015).

\section{October 2002}

The eruption of Mount Etna that began on 27 October 2002 and finally ceased on 28 January 2003 was one of the most explosive events of the last few centuries with eruption columns up to $7 \mathrm{~km}$ a.s.l. (Andronico et al. 2005). Whilst this eruption would be dwarfed by the repeated paroxysms of Etna in 2021, the ash during this most recent eruption did not fall on Malta, instead passing a few kilometres to the east. By comparison, ash from the 2002 eruption was recorded as falling on Malta on 27 October and was described as having "coated the country in an insidious film of black dust [... resulting in] homes and cars being covered in soot" (Zammit 2002). Although the flanks of the volcano are visible from Malta, the local press reported general confusion and several conspiracy theories regarding the source of the "soot". These included: the principal power station; the waste dump; the hospital chimney; local hotels; a passing ship, and a passing warplane (Zammit 2002). A higher magnitude event and an appropriate wind direction could close Malta's international airport with a devastating effect on the tourist and wider economies (Azzopardi et al. 2013; Main 2019; Main et al. 2021).

\section{November 2014}

A peculiar feature of the Mediterranean Sea is the formation of low-pressure cyclonic systems which are known as medicanes (Romero and Emanuel 2013; Cavicchia et al. 2014). One of the most widely reported instances of medicane impact on Malta was Medicane Qendresa that made landfall at around 16:30 LT on 7 November 2014, with wind speeds of up to $154 \mathrm{~km} \mathrm{~h}^{-1}$, sustained winds of c. $113 \mathrm{~km} \mathrm{~h}^{-1}$ and c. $3 \mathrm{~m}$ high waves in the Sicily Channel (Masters 2014).

Damage from this event was extensive and contemporary accounts focused on the damage that resulted from winds inland. Fortunately there were no reports of injuries or fatalities. Much damage and disruption was caused to the transport network, with roads blocked, flights and inter-island ferry services suspended and, in one instance, road tailbacks up to 4-5 km. Streets were flooded, cars, walls and in some instances houses were damaged and trees were uprooted across Malta. Large areas experienced a blackout as electricity poles were blown down (Martin 2014; Muscat 2014). Unfortunately, not much is recorded about the damage caused by the high waves and possible storm surges, although this is likely to have posed a significant threat to settlements and critical infrastructure along the coast (Main 2019). 
Recognised internationally as one of the images of Gozo, if not the whole island state, It-Tieqa tad Dwejra (i.e. The Window of Dwejra or The Azure Window) was a $30 \mathrm{~m}$ high seastack and arch on the northwest coast of Gozo believed to have formed between 1866-1879 (Carabott 2017; Satariano and Gauci 2019; Fig. 4). Featuring in major blockbuster movies and television series such as Game of Thrones and Clash of the Titans, the arch extended $60 \mathrm{~m}$ into the Mediterranean. Significant erosion over the preceding three decades, and particularly between 2010-2017, had weakened the arch with up to $90 \%$ of the lower rock formed from Lower Coralline Limestone collapsing during previous storms (Gatt 2013; Carabott 2017). During the storm of 7-9 March 2017, strong north-westerly winds reached speeds of c. $72 \mathrm{~km}$ $\mathrm{h}^{-1}$ off Gozo's northwest coast generating wave heights of up to $3 \mathrm{~m}$ and these factors combined to cause the arch to collapse (Galea et al. 2018).

At 09:32:11 LT on 8 March and to the surprise of local people and scientists, the stack collapsed with a 'loud whoomph' into the sea below, with scientists estimating that c. 38 million kg of rock was involved (Anon 2017b; Caruana 2017; Galea et al. 2018). Following a report by Gatt (2013) fines were levied and fences and later security officers were hired to protect the arch from continued erosion from tourist foot-fall and tourists from the dangers posed by the rapidly eroding arch (Satariano and Gauci 2019). Fortunately, with the exception of the two recently-hired security officers and a local resident watching the storm, the area was devoid of visitors. Despite its recent date, there is no video or photographic record of this event.

\section{Conclusion}

The city-island-state of Malta has traditionally been viewed as a low-hazard, advanced and independent archipelagic island state in the central Mediterranean with a complex setting and physical geography. This view is due in part to a lack of long historical records of environmental extremes and their impacts on Malta, a situation which has created difficulties in formulating detailed hazard assessments and evidence-based policies of DRR on this heavily populated city-island-state. Islands such as Malta have long been overlooked given the infrequency of damaging events, yet in the future impacts from such events may be highly significant given the rate of continued economic development and growth in the population at risk.

In this paper and accompanying supplementary material, we have compiled over 3,500 documents and points of reference, and have established the first multi-hazard historical 
catalogue for Malta. In so doing, we identify at least 1,526 hazardous events that have claimed at least 661 lives and which have encompassed geophysical, geomorphological and meteorological extremes. This represents a significant advance in understanding the timing, frequency and impact of environmental extremes on Malta. Such events include: local, regional and distal earthquakes; putative effects of volcanic eruptions; coastal erosion; tornadoes; medicanes; sand-storms; flooding and drought. The majority of these events are considered reliable with $78 \%$ having a reliability of 3 (confirmed) or 4 (definite), whilst only $1 \%$ are considered questionable. Additional work in this area is required, however, notably to identify any events that are still absent from the record. Recognising the continuing economic and physical transformations of the city-island-state, it is further critical to model the impacts of past events on contemporary Malta in order to inform the development of public-facing and evidence-based policies and practices of disaster risk reduction, all of which are key recommendations and objectives of Malta's risk reduction and management strategy.

\section{References}

Abela M (1969) Earthquakes in Malta. Dissertation, University of Malta.

Agius MR, Galea P, Farrugia D, D'Amico S (2020) An instrumental earthquake catalogue for the offshore Maltese islands region, 1995-2014. Ann Geophys 63:SE658. https://doi.org/10.4401/ag-8383.

AIG Malta (2017) National Flood Relief Project. AIG Malta. http://www.aigmalta.eu/. Accessed 13 October 2017.

Alexander D (1988) A review of the physical geography of Malta and its significance for tectonic geomorphology. Quat Sci Rev 7:41-53. https://doi.org/10.1016/0277-3791(88)900923 .

Alexander D (2014) Social Media in Disaster Risk Reduction and Crisis Management. Sci Eng Ethics 20:717-733. https://doi.org/10.1007/s11948-013-9502-z.

Andronico D, Branca S, Calvari S et al (2005) A multi-disciplinary study of the 2002-03 Etna eruption: insights into a complex plumbing system. Bull Volcanol 67:314-330. https://doi.org/10.1007/s00445-004-0372-8.

Anon (1980) No-one missing in bay after cliff-face collapse. Times of Malta, 8 September, $p$ 9.

Anon (2017a) British and European Tornado Extremes. The Tornado and Storm Research Organisation. http://www.torro.org.uk/whirlwind_info.php. Accessed 3 July 2018.

Anon (2017b) The Azure Window lost and gone forever. Times of Malta. https://www.timesofmalta.com/articles/view/20170308/local/the-azure-window-lost-andgone-forever.641810. Accessed 25 July 2018. 

to encourage disaster preparedness: Lessons from a low-hazard country. Int J Disast Risk Re 31:37-44. https://doi.org/10.1016/j.ijdrr.2018.04.015.

Attard M (2015) The Impact of Global Environmental Change on Transport in Malta. Xjenza Online 3:141-152. https://www.um.edu.mt/library/oar/handle/123456789/8327.

Azzopardi F, Ellul R, Prestifilippo M, Scollo S, Coltelli M (2013) The effect of Etna volcanic ash clouds on the Maltese Islands. J Volcanol Geotherm 260:13-26. https://doi.org/10.1016/j.jvolgeores.2013.04.019.

Baldassini N, Di Stefano A (2017) Stratigraphic features of the Maltese Archipelago: a synthesis. Nat Hazards 86:203-231. https://doi.org/10.1007/s11069-016-2334-9.

Barbano MS, Rigano R (2001) Earthquake sources and seismic hazard in Southeastern Sicily. Ann Geofis 44(4):723-738.

Biolchi S, Furlani S, Antonioli F et al (2016) Boulder accumulations related to extreme wave events on the eastern coast of Malta. Nat Hazards Earth Syst Sci 16:737-756. https://doi.org/10.5194/nhess-16-737-2016.

Bonnici H, Gatt N, Spiteri S, Valentino J (2008) Vilhena Palace and underlying bastions (Mdina, Malta) - A multi-disciplinary approach in defining a consolidation intervention. Geogr Fis Dinam Quat 31:99-105.

Branca S, Del Carlo P (2004) Eruptions of Mt Etna during the past 3,200 years: a revised compilation integrating the historical and stratigraphic records. In: Bonaccorso A, Calvari S, Coltelli M, Del Negro C, Falsaperla S (eds) Mt. Etna: Volcano Laboratory. AGU Geophysical Monograph Series 143, pp 1-27. http://hdl.handle.net/2122/10586.

Branca S, Azzaro R, De Beni E, Chester D, Duncan A (2015) Impacts of the 1669 eruption and the 1693 earthquakes on the Etna Region (Eastern Sicily, Italy): An example of recovery and response of a small area to extreme events. J Volcanol Geotherm 303:25-40. https://doi.org/10.1016/j.jvolgeores.2015.07.020.

Calleja I (2010) Solution subsidence structures (dolines) in Malta: Their physical development and human use. Dissertation, University of Malta. https://www.um.edu.mt/library/oar/handle/123456789/73392.

Camilleri DH (2006) Tsunami construction risks in the Mediterranean - outlining Malta's scenario. Disaster Prev Manag 15: 146-162. https://doi.org/10.1108/09653560610654301.

Camilleri I (2011) Malta is ‘safest place on Earth’. Times of Malta, 19 February, pp 28-29.

Carabott S (2015) One day a cliff crashed down to the beach below. Times of Malta, 9 August.

Carabott S (2017) Was the Azure Window really just 140 years old? Times of Malta. https://www.timesofmalta.com/articles/view/20170313/local/was-the-azure-window-reallyjust-140-years-old.642277. Accessed 2 July 2021. 
Caruana C (2017) Nature closes window on Gozitan heritage. Times of Malta, 9 March, pp 89.

Causon Deguara J, Gauci R (2017) Evidence of extreme wave events from boulder deposits on the south-east coast of Malta (Central Mediterranean). Nat Hazards 86:543-568. https://doi.org/10.1007/s11069-016-2525-4.

Cavicchia L, von Storch H, Gualdi S (2014) Mediterranean Tropical-Like Cyclones in Present and Future Climates. J Clim 27:7493-7501. https://doi.org/10.1175/JCLI-D-14-00339.1.

Chatzimpaloglou P, Schembri PJ, French C, Ruffell A, Stoddart S (2020) The geology, soils and present-day environment of Gozo and Malta. In: French C, Hunt CO, Grima R, McLaughlin R, Stoddart S, Malone C (eds) Temple landscapes: Fragility, change and resilience of Holocene environments in the Maltese Islands. McDonald Institute Monographs, Cambridge, UK, pp 19-34.

Ciarlò J (ed) (2017) The Seventh National Communication of Malta under the United Nations Framework Convention on Climate Change.

der Heide EA (2004) Common misconceptions about disasters: Panic, the "Disaster Syndrome", and looting. In: O'Leary M (ed) The First 72 Hours: A Community Approach to Disaster Preparedness. iUniverse Publishing, Lincoln, Nebraska, pp 340-380.

Devoto S, Biolchi S, Bruschi VM et al (2012) Geomorphological map of the NW Coast of the Island of Malta (Mediterranean Sea). J Maps 8(1):33-40. https://doi.org/10.1080/17445647.2012.668425.

Devoto S, Hastewell LJ, Prampolini M, Furlani S (2021) Dataset of Gravity-Induced Landforms and Sinkholes of the Northeast Coast of Malta (Central Mediterranean Sea). Data 6:81. https://doi.org/10.3390/data6080081.

Galdies C (2011) The Climate of Malta: statistics, trends and analysis 1951-2010. National Statistics Office, Valletta, Malta.

European Commission (2016) Peer Review - Malta 2016. European Commission, Brussels.

Furlani S, Antonioli F, Gambin T et al (2017) Marine Notches in the Maltese Islands (Central Mediterranean Sea). Quat Int 439:158-168. https://doi.org/10.1016/j.quaint.2016.03.004.

Furlani S, Vaccher V, Antonioli F et al (2021) Preservation of Modern and MIS 5.5 Erosional Landforms and Biological Structures as Sea Level Markers: A Matter of Luck? Water 13(15):2127. https://doi.org/10.3390/w13152127.

Galea P (2007) Seismic history of the Maltese Islands and considerations on seismic risk. Ann Geophys 50:725-740.

Galea P (2019) Central Mediterranean Tectonics - a key player in the geomorphology of the Maltese Islands. In: Gauci R, Schembri JA (eds) Landscapes and Landforms of the Maltese Islands. Berlin, Springer, pp 19-30. https://doi.org/10.1007/978-3-030-15456-1_3.

Galea P, Bozionelos G, D’Amico S, Drago A, Colica A (2018) Seismic Signature of the Azure Window Collapse, Gozo, Central Mediterranean. Seismol Res Lett 89:1108-1117. https://doi.org/10.1785/0220170115. 

Tsunamis in the Canary Islands: Implications for Tsunami Risk Reduction. Geosciences 11:222. https://doi.org/10.3390/ geosciences11050222.

547

548

549

550

551

552

553

554

555

556

557

558

559

560

561

562

563

564

565

566

567

568

569

570

571

572

573

574

575

576

577

578

579

580

581

582

Gaspar JL, Queiroz G, Ferreira T et al (2015) Earthquakes and volcanic eruptions in the Azores region: geodynamic implications from major historical events and instrumental seismicity. In: Gaspar JL, Guest JE, Duncan AM, Barriga FJAS, Chester DK (eds) Volcanic Geology of São Miguel Island (Azores Archipelago) Geological Society, London 44, pp 33-49. http://doi.org/10.1144/M44.4.

Gatt P (2013) Geological and geotechnical report on the Azure Window, Gozo: Rock assessment and recommendations for preservation and conservation. Geoscience Consulting Technical Report, MG22/2005.

Gauci A (2021) Killer waves that threaten our shores. Times of Malta. https://timesofmalta.com/articles/view/killer-waves-that-threaten-our-shores.860986.

Accessed 9 June 2021.

Gauci R, Scerri S (2019) A Synthesis of Different Geomorphological Landscapes on the Maltese Islands. In: Gauci R, Schembri JA (eds) Landscapes and Landforms of the Maltese Islands. Berlin, Springer, pp 49-65. https://doi.org/10.1007/978-3-030-15456-1_5.

Gauci R, Schembri JA (2019) Introduction to Landscapes and Landforms of the Maltese Islands. In: Gauci R, Schembri JA (eds) Landscapes and Landforms of the Maltese Islands. Berlin, Springer, pp 1-5. https://doi.org/10.1007/978-3-030-15456-1_1.

Gigli G, Frodella W, Mugnai F et al (2012) Instability mechanisms affecting cultural heritage sites in the Maltese Archipelago. Nat Hazards Earth Syst Sci 12:1883-1903. https://doi.org/10.5194/nhess-12-1883-2012.

Gutiérrez F, Parise M, De Waele J, Jourde H (2014) A review on natural and human-induced hazards in karst. Earth Sci Rev 138:61-88. https://doi.org/10.1016/j.earscirev.2014.08.002.

IPCC (2021) IPCC Sixth Assessment Report Working Group 1. IPCC. https://www.ipcc.ch/report/ar6/wg1/. Accessed 12 August 2021.

IPCC/NASA (2021) Sea Level Projection Tool. IPCC/NASA. https://sealevel.nasa.gov/ipccar6-sea-level-projection-tool. Accessed 13 August 2021.

Jones A (2018) Case Study Malta: Climate Change and Tourism: Risks, Hazards and Resilience - An Island Perspective. In: Jones AL, Phillips M (eds) Global Climate change and Coastal Tourism: Recognising Problems, Managing Solutions and Future Expectations. CABI, Wallingford, pp 138-146.

Kennedy V, Crawford KR, Main G, Gauci R, Schembri JA (2020) Stakeholder's (natural) hazard awareness and vulnerability of small island tourism destinations: a case study of Malta. Tourism Recreation Research. https://doi.org/10.1080/02508281.2020.1828554.

Macdonald N, Jones CA, Davies SJ, Charnell-White CA (2010) Historical weather accounts from Wales: an assessment of their potential for reconstructing climate. Weather 65:72-81. https://doi.org/10.1002/wea.418. 
Main G (2019) Natural Hazards, Vulnerability and Resilience of the Maltese Islands. Dissertation, Liverpool Hope University.

Main G, Schembri J, Gauci R et al (2018) The hazard exposure of the Maltese Islands. Nat Hazards 92:829-855. https://doi.org/ 10.1007/s11069-018-3227-x.

Main G, Schembri JA, Speake J, Gauci R, Chester D (2021) The city-island-state, wounding cascade, and multi-level vulnerability explored through the lens of Malta. Area 53:272-282. https://doi.org/10.1111/area.12709.

Malta Resources Authority (2013) Preliminary Flood Risk Assessment: Final Report May 2013. Malta Resources Authority.

Malta Tourism Authority (2020) Tourism in Malta: Facts \& Figures 2019. Malta Tourism Authority.

Mantovani M, Devoto S, Forte E et al (2013) A multidisciplinary approach for rock spreading and block sliding investigation in the north-western coast of Malta. Landslides 10:611-622. https://doi.org/10.1007/s10346-012-0347-3.

Maramai A, Brizuela B, Graziani L (2014) The Euro-Mediterranean Tsunami Catalogue. Ann Geophys 57:S0435. https://doi.org/10.4401/ag-6437.

Martin I (2014) “In the morning I had a car, by the evening I just didn't." Times of Malta, 9 November, $\mathrm{p} 6$.

Masters J (2014) Rare Medicane hits Malta and Sicily with tropical storm-like conditions. Wunderground. http://www.wunderground.com/blog/JeffMasters/rare-medicane-hits-maltaand-sicily-with-tropical-stormlike-condition.html. Accessed 10 November 2017.

McDonald JR (2002) 6.1 Development of an Enhanced Fujita Scale for Estimating Tornado Intensity. https:// doi.org/10.1.1.453.1799.

Méheux K, Dominey-Howes D, Lloyd K (2007) Natural hazard impacts in small island developing states: A review of current knowledge and future research needs. Nat Hazards 40:429-446. https://doi.org/ 10.1007/s11069-006-9001-5.

Morrison C (2013) An Initial Assessment of the Tsunami Risk in Malta, Including Recommendations for Disaster Risk Reduction. Dissertation, University of Glamorgan.

Mottershead DN, Bray MJ, Soar PJ (2018) Tsunami landfalls in the Maltese archipelago: reconciling the historical record with geomorphological evidence. Geol Soc Spec Publ 456:127-141. https://doi.org/10.1144/SP456.8.

Mueller C, Micallef A, Spatola D, Wang X (2020) The Tsunami Inundation Hazard of the Maltese Islands (Central Mediterranean Sea): A Submarine Landslides and Earthquake Tsunami Scenario Study. Pure Appl Geophys 177:1617-1638. https://doi.org/10.1007/s00024019-02388-w.

Muscat C (2014) Airport, ferry halted as cyclone ravages island. Times of Malta, 8 November, pp $1,4$. 
620 National Statistics Office. World Population Day: 11 July 2020.

621 https://nso.gov.mt/en/News_Releases/Documents/2020/07/News2020_114.pdf. Accessed 11

622 July 2020.

623 Oil Exploration Directorate (1993) Geological Map of the Maltese Islands, Sheet 1 and 2 624 Malta, Gozo and Comino. Scale: 1:25,000, Office of the Prime Minister, resurveyed by Pedley 625 HM, revised by Debono G, Scerri S, cartographer Simpson C. British Geological Survey, 626 Keyworth.

627 Pararas-Carayannis G (2011) The earthquake and tsunami of July 21, 365 AD in the Eastern 628 Mediterranean Sea-Review of Impact on the Ancient World-Assessment of Recurrence and 629 Future Impact. Sci Tsunami Hazards 30(4):253-292.

630 Pareschi MT, Boschi E, Favalli M (2006) Lost tsunami. Geophys Res Lett 33:L22608. 631 https://doi.org/10.1029/2006GL027790.

632 Pedley HM (1974) Miocene sea-floor subsidence and lateral subaerial solution subsidence 633 structures in the Maltese Islands. Proc Geol Assoc 85(4):533-547. 634 https://doi.org/10.1016/S0016-7878(74)80074-X.

635 Pedley HM, Clarke MH, Galea P (2002) Limestone isles in a crystal sea, the geology of the 636 Maltese Islands. Malta, PEF Ltd.

637 Pelling M, Uitto JI (2001) Small island developing states: natural disaster vulnerability and 638 global change. Environmental Hazards 3:49-62. https://doi.org/10.3763/ehaz.2001.0306.

639 Prampolini M, Gauci C, Micallef AS et al (2018) Geomorphology of the north-eastern coast of 640 Gozo (Malta, Mediterranean Sea). J 14:402-410 641 https://doi.org/10.1080/17445647.2018.1480977.

642 Raška P, Zábransky V, Dubišar J et al (2014) Documentary proxies and interdisciplinary 643 research on historic geomorphic hazards: a discussion of the current state from a central 644 European perspective. Nat Hazards 70:705-732. https://doi.org/10.1007/s11069-013-0839-z.

645 Riede F (2014) Towards a science of past disasters. Nat Hazards 71:335-362. 646 https://doi.org/10.1007/s11069-013-0913-6.

647 Romero R, Emanuel K (2013) Medicane risk in a changing climate. J Geophys Res, 118:5992648 6001. https://doi.org/10.1002/jgrd.50475.

649 Satariano B, Gauci R (2019) Landform Loss and Its Effect on Health and Well-being: The 650 Collapse of the Azure Window (Gozo) and the Resultant Reactions of the Media and the 651 Maltese Community. In: Gauci R, Schembri JA (eds) Landscapes and Landforms of the 652 Maltese Islands. Berlin, Springer, pp 289-303. https://doi.org/10.1007/978-3-030-15456-1_23.

653 Scerri S (2019) Sedimentary Evolution and Resultant Geological Landscapes, in: Landscapes 654 and Landforms of the Maltese Islands. In: Gauci R, Schembri JA (eds) Landscapes and 655 Landforms of the Maltese Islands. Berlin, Springer, pp 31-47, https://doi.org/10.1007/978-3656 030-15456-1_4. 
657

658

659

660

661

662

663

664

665

666

667

668

669

670

671

672

673

674

675

676

677

678

679

680

681

682

683

684

685

686

687

688

689

690

Schembri D (2010) Local flooding by design. Times of Malta. http://www.timesofmalta.com/articles/view/20101101/local/flooding-by-design.334091. Accessed 27 May 2016.

Schembri JA (2003) Coastal land use in the Maltese islands: a description and appraisal. Dissertation, University of Durham. http://etheses.dur.ac.uk/4417.

Schembri JA (2019) The Geographical Context of the Maltese Islands. In: Gauci R, Schembri JA (eds) Landscapes and Landforms of the Maltese Islands. Berlin, Springer, pp 9-17. https://doi.org/10.1007/978-3-030-15456-1_2.

Shower J (1693) Practical Reflections on the Late Earthquakes in Jamaica, England, Sicily, Malta \&c. Anno 1692 With a Particular, Historical Account of them, and drivers other Earthquakes. London.

Soldati M, Devoto S, Prampolini M, Pasuto A (2019) The spectacular landslide-controlled Landscape of the Northwestern Coast of Malta. In: Gauci R, Schembri JA (eds) Landscapes and Landforms of the Maltese Islands. Berlin, Springer, pp 167-178. https://doi.org/10.1007/978-3-030-15456-1_14.

Soldati M, Tonelli C, Galve JP (2013) Geomorphological evolution of palaeosinkhole features in the Maltese archipelago (Mediterranean Sea). Geogr Fis Dinam Quat 36:189-198. https://doi.org/10.4461/GFDQ.2013.36.16.

Tappin DR (2018) The importance of geologists and geology in tsunami science and tsunami hazard. In: Scourse EM, Chapman NA, Tappin DR, Wallis SR (eds) Tsunamis: Geology, Hazards and Risks. Special Publications of the Geological Society, London, pp 5-38. https://doi.org/10.1144/SP456.11.

Tinti S, Maramai A, Graziani L (2004) The New Catalogue of Italian Tsunamis. Nat Hazards 33(3):439-465. https://doi.org/10.1023/B:NHAZ.0000048469.51059.65.

United Nations (2015) Sendai Framework for Disaster Risk Reduction 2015-2030. UNISDR, Geneva.

Vella L, Tanti CM, Rolé A (2005) Coastal Area Management in Malta. UNEP Priority Actions Programme Regional Activity Centre, Split.

Villani F, D’Amico S, Panzera F et al (2018) Shallow high-resolution geophysical investigation along the western segment of the Victoria Lines Fault (island of Malta). Tectonophysics 724725:220-233. https://doi.org/10.1016/j.tecto.2018.01.010.

Wisner B, Gaillard JC (2009) An introduction to neglected disasters. Jamba: J Disaster Risk Stud 2(3):151-158. https://hdl.handle.net/10520/EJC51175.

691

Zammit R (2002) Malta covered in ash from Mount Etna. Times of Malta, 28 October, p 1. 
693 Table 1 The four-point ranking scale used in the historical catalogue.

694 Table 2 The hazard exposure of Malta by district and recorded occurrences within the historical 695 catalogue.

696 Figure 1 The geological and tectonic structure and setting of Malta. Adapted after Oil 697 Exploration Directorate (1993) and Main (2019).

698 Figure 2 Example historical records of Malta's hazardous history: a) boulder deposits at 699 Xghajra possibly emplaced by an extreme wave event, photo by R. Gauci; b) erosional socket 700 at Ahrax Point possibly emplaced by an extreme wave event, photo by G. Main; c) the Il701 Kantilena poem believed to have been written pre-1485 about a ground collapse event, image 702 by H. de Guettelet (Wikimedia Commons CC Attribution-Share Alike 3.0); d) video of tornadic 703 waterspout on 10 November 2017, New.Info.Hoje YouTube channel 704 (https://www.youtube.com/watch?v=Yj6zE-McnMw).

705 Figure 3 Mass movement phenomena along the coastline: a) rock-fall at Ghar Hasan, photo by 706 R. Gauci; b) rock-fall at Ghar Lapsi, photo by R. Gauci; c) block sliding and rock-fall at Golden 707 Bay, photo by G. Main; d) block sliding above Popeye Village, Anchor Bay, photo by F. König 708 (Wikimedia Commons, GNU Free Documentation Licence Version 1.2); e) rock-fall at Xwejni 709 Bay, photo by G. Main.

710 Figure 4 The Azure Window, Dwejra: a) August 2006, photo by G. Bowman (Wikimedia 711 Commons CC Attribution 2.0 Generic); b) 26 February 2017, photo by G. Main; c) June 2017, 712 photo by A. Hepworth and reproduced with permission. 
Figures

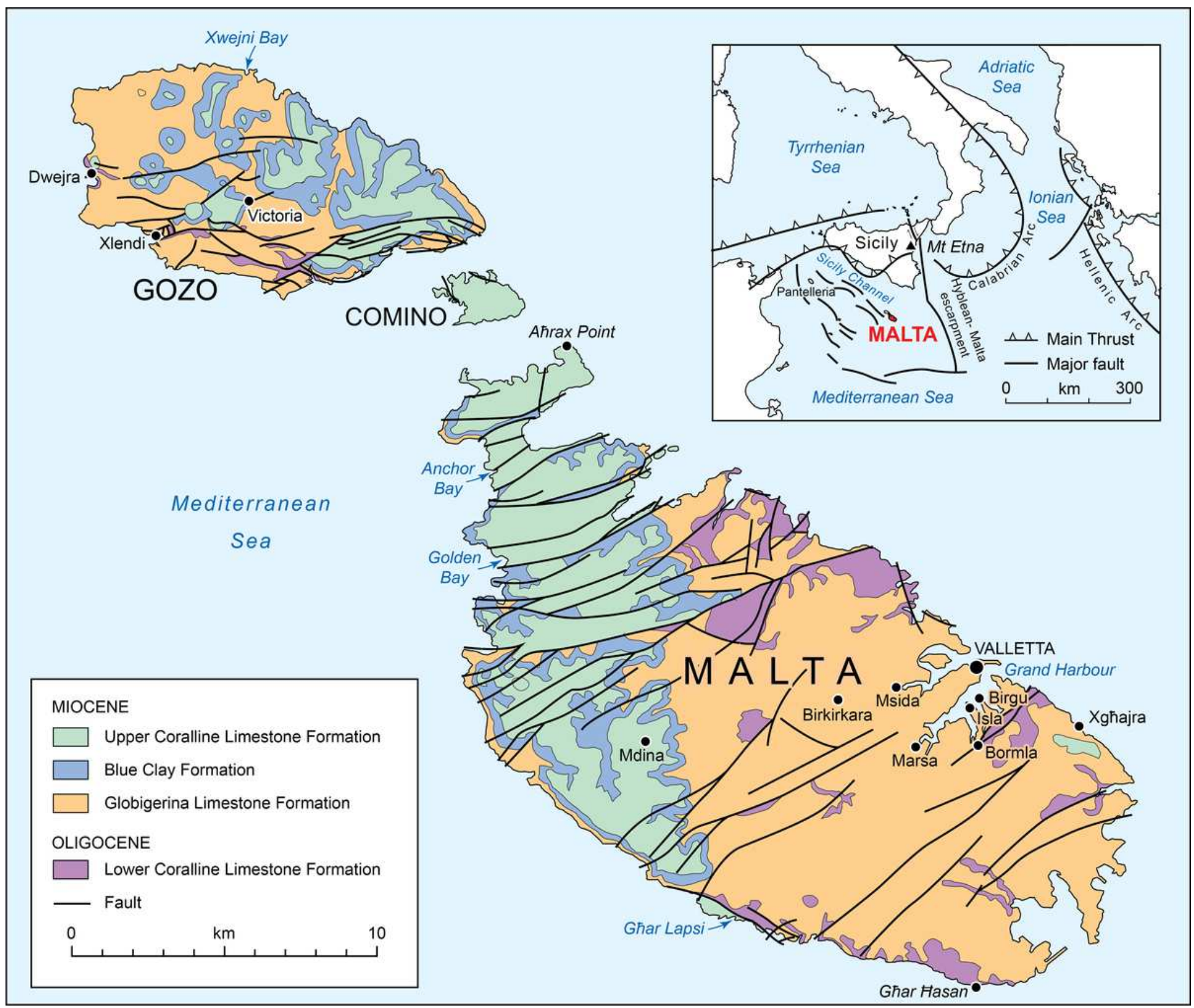

\section{Figure 1}

The geological and tectonic structure and setting of Malta. Adapted after Oil Exploration Directorate (1993) and Main (2019). 

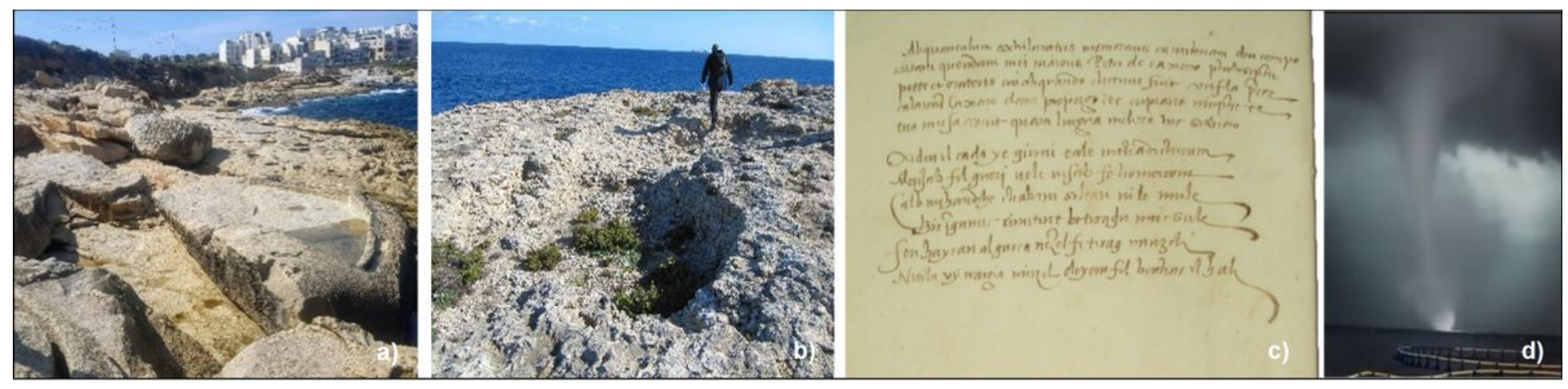

Figure 2

Example historical records of Malta's hazardous history: a) boulder deposits at Xghajra possibly emplaced by an extreme wave event, photo by R. Gauci; b) erosional socket at Aћrax Point possibly emplaced by an extreme wave event, photo by G. Main; c) the II-Kantilena poem believed to have been written pre-1485 about a ground collapse event, image by H. de Guettelet (Wikimedia Commons CC Attribution-Share Alike 3.0); d) video of tornadic waterspout on 10 November 2017, New.Info.Hoje YouTube channel (https://www.youtube.com/watch?v=Yj6zE-McnMw).

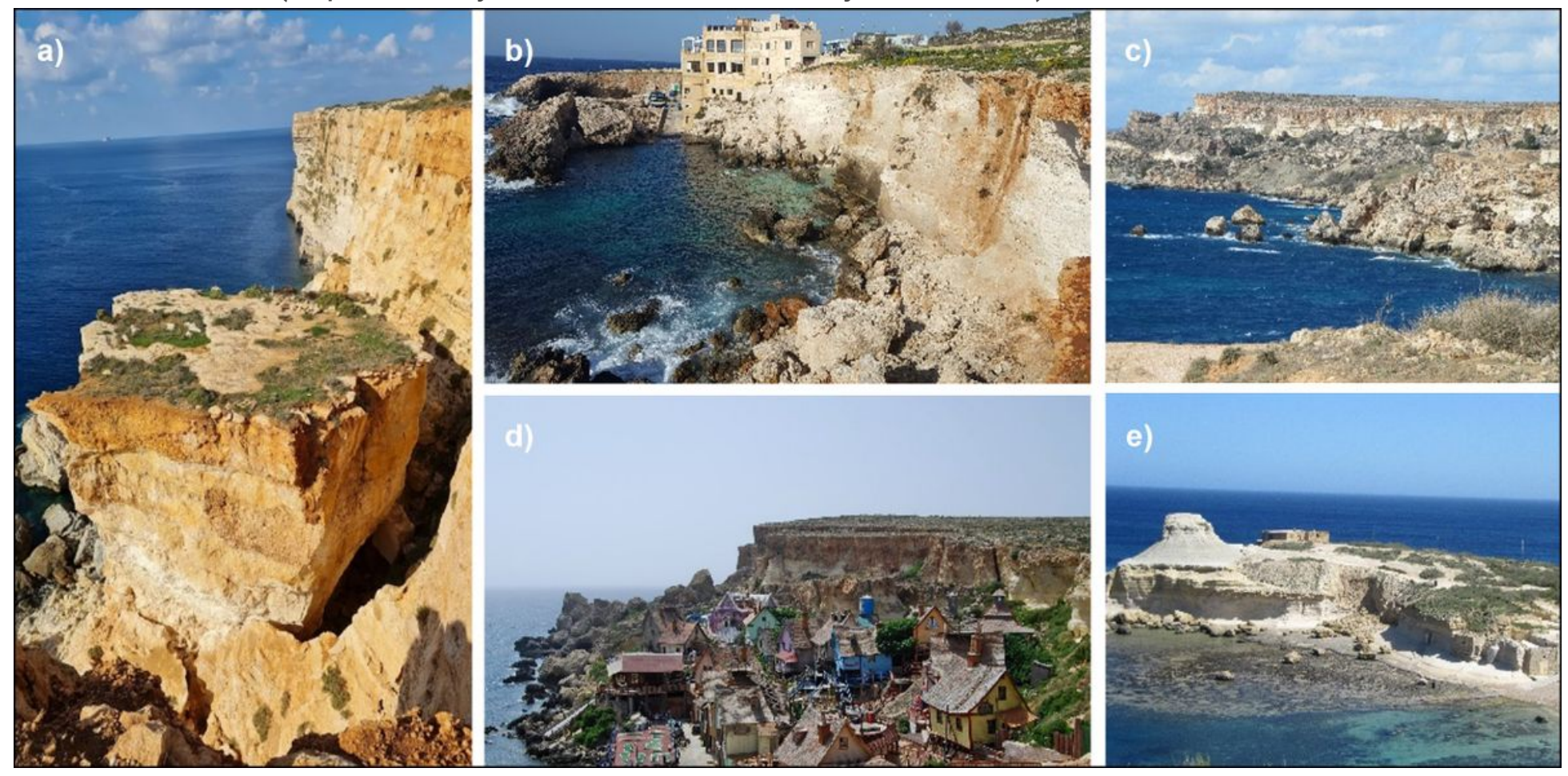

Figure 3

Mass movement phenomena along the coastline: a) rock-fall at Ghar Hasan, photo by R. Gauci; b) rockfall at Ghar Lapsi, photo by R. Gauci; c) block sliding and rock-fall at Golden Bay, photo by G. Main; d) block sliding above Popeye Village, Anchor Bay, photo by F. König (Wikimedia Commons, GNU Free Documentation Licence Version 1.2); e) rock-fall at Xwejni Bay, photo by G. Main. 


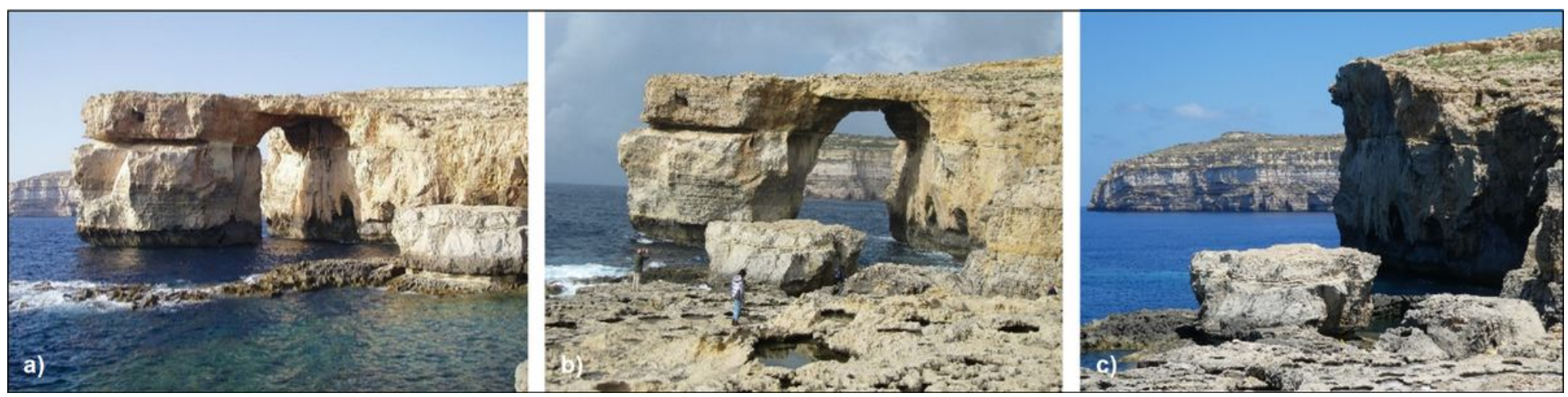

\section{Figure 4}

The Azure Window, Dwejra: a) August 2006, photo by G. Bowman (Wikimedia Commons CC Attribution 2.0 Generic); b) 26 February 2017, photo by G. Main; c) June 2017, photo by A. Hepworth and reproduced with permission.

\section{Supplementary Files}

This is a list of supplementary files associated with this preprint. Click to download.

- Table1.pdf

- Table2.pdf

- supplementarymaterial.pdf 